Article

\title{
Exploring Negative Spillover Effects on Stakeholders: A Case Study on Social Media Talk about Crisis in the Food Industry Using Data Mining
}

\author{
Dorit Zimand-Sheiner ${ }^{1, *} \mathbb{*}$, Shalom Levy ${ }^{2} \mathbb{D}$ and Eyal Eckhaus ${ }^{2}$ (D) \\ 1 School of Communication, Ariel University, Science Park, POB 3, Ariel 40700, Israel \\ 2 Department of Economics and Business Administration, Ariel University, Science Park, POB 3, \\ Ariel 40700, Israel; shalom@ariel.ac.il (S.L.); eyale@ariel.ac.il (E.E.) \\ * Correspondence: doritzs@ariel.ac.il
}

Citation: Zimand-Sheiner, D.; Levy, S.; Eckhaus, E. Exploring Negative Spillover Effects on Stakeholders: A Case Study on Social Media Talk about Crisis in the Food Industry Using Data Mining. Sustainability 2021, 13, 10845. https://doi.org/ $10.3390 /$ su131910845

Academic Editor:

Amalia Triantafillidou

Received: 26 August 2021

Accepted: 24 September 2021

Published: 29 September 2021

Publisher's Note: MDPI stays neutral with regard to jurisdictional claims in published maps and institutional affiliations.

Copyright: (c) 2021 by the authors. Licensee MDPI, Basel, Switzerland. This article is an open access article distributed under the terms and conditions of the Creative Commons Attribution (CC BY) license (https:// creativecommons.org/licenses/by/ $4.0 /)$.

\begin{abstract}
Focusing on public-centered, social-mediated crisis communication, the current exploratory study drew on situational crisis communication theory to formulate a comprehensive view of consumer reactions to crisis. Data mining and automated content analysis techniques were utilized to analyze social media posts by the public during a crisis in the cereals industry. Two path analyses showed that: (a) crisis-related social media posts tended to skip over competitor brand products, followed by two major reaction paths-(1) a rational path based on guilt attribution that justifies implications for the company and (2) an emotional path associated with public distrust; and (b) public self-blame spilled over to other stakeholders such as the government and economic system. The results give voice to issues that concern the public during crises, both as individuals and as a community. They highlight the fact that sustainable crisis management should involve additional stakeholders. Conclusions and implications for society and practice are suggested.
\end{abstract}

Keywords: corporate sustainability; stakeholders; crisis management; social media; situational crisis communication theory; data mining

\section{Introduction}

Organizational crisis is "a major, unexpected event, foreseen or unpredicted, that threatens the sustainability of the organization and can have meaningful consequences for the future of the organization." [1]. Thus, firms' crisis situations have a high influence on corporate sustainability. One of the effects of crisis situations is their considerable influence on the relationship between business and stakeholders, as these relationships are important to achieve organizational objectives and maintain sustainability [2]. Therefore, recognizing the stakeholders involved in the issues raised by the public while discussing a crisis may help firms' short-term resilience to crisis and maintain long-term sustainability [1].

Social media can be a valuable tool to examine communication dynamics of stakeholders, regarding the under-crisis organization [3] and created new opportunities to study crisis-related communication [3-9]. These social-media based studies are referred to as "crisis informatics" [10], "social-mediated dialogue", or "social-mediated crisis communication" research [4].

Crisis communication research can be characterized by two main approaches: (1) organizationcentered and (2) public-centered. The organization-centered approach is message-sender oriented, focusing on messages sent by the crisis manager and looking at how optimal messaging strategies can retain the public's trust in an organization and maintain its reputation [11-13]. The public-centered approach focuses on the receiver side of crisis communication, exploring the effect of organizational messages on receivers. A considerable body of research is, therefore, dedicated to evaluating public reactions to crisis-related messages on social media - whether positive or negative [5,11,14-16]. 
Arguably, public-centered research represents an advance over organization-centered research, as it takes account of both sender concerns (such as image-related concerns of the organization) and receiver concerns (the wellbeing, feelings, and health concerns of those who receive the communication) in the crisis-communication process [12]. Hence, this approach, like its organization-centered counterpart, can nevertheless be used by organizations to monitor and analyze consumer reactions to organizational crisis communication. For instance, recent studies have shown that when the public is affected by a crisis, it is concerned with a variety of issues, such as government intervention and other related brands $[17,18]$. These issues, which involve additional stakeholders beyond the crisis organization and the public, are neglected in the literature.

Most crisis-communication studies use the term stakeholders to refer to the public or to individuals as message receivers of crisis communication. In this study, we adopted a more managerial approach to stakeholders in order to differentiate them from the public. Stakeholders were defined as organizations and/or individuals with an interest in the organization in crisis that have the power to affect how the crisis is managed and perceived [19]. Thus, we use this term to relate to all organizations included in crisis-related conversations instigated by the public on social media. This approach allowed for this study on crises to observe a variety of stakeholders who may be perceived to have shared responsibility for crises or may be influenced by the spillover effect of a crisis. Consequently, expanding the scope from the under-crisis organization and the public to other stakeholders involved in the crisis may raise more managerial and communication issues that the organization as well as their stakeholders need to address.

One of the threats to a firm's relationship with its stakeholders is negative reputation spillover, which refers to a situation wherein the reputational damage to the under-crisis organization affects the reputation of other organization [20,21]. Previous research examined the negative spillover effect of organizations and brands in the same or closely related industries [20-22], the home country of the under-crisis brand [23], the government [17], and even international markets [24]. The crisis spillover effect is a double-edged sword: from one side, it may enhance the crisis in publics' perceptions, undermining their trust in innocent firms [22]. This may intensify the crisis and even damage the relationship of the under-crisis organization with its industry. From the other side, the attribution of responsibility to various stakeholders, such as the government, may also lead to regulatory intervention in and even beyond the crisis [17].

Crisis communication theories such as the well-known situational crisis communication theory (SCCT) [25] offer principles for crisis-communication management, concentrating on under-crisis organizations and their communication strategy toward the public. Given the suggested wider scope of stakeholders involved in crises and the negative spillover effect, these theories should be adjusted to include under-crisis organization communication with various stakeholders other than the public as well as develop communication strategies for stakeholders that are indirectly affected by the crisis.

Following the abovementioned observations, this study had three main goals:

1. Evaluate the most frequent issues raised by the public while addressing a crisis on social media.

2. Reveal the variety of stakeholders that the public involves in talk about crisis.

3. Explore the relationships among these issues and stakeholders mentioned by the public.

This study was based on public reactions on social media to the Unilever-Telma crisis involving Salmonella bacteria pollution in its cereal brands. The study illustrates how attribution of responsibility expanded to various stakeholders. Expanding the scope from organization-related posts to all posts relating to the crisis may result in a new perspective for crisis management. Exploiting the opportunities in the era of social media to accumulate information enabled the investigation of a real case study instead of using artificial stimuli. Moreover, this study used innovative computerized big data techniques that serve as tools to attain new insights into consumer responses to crisis. In order to broaden the data on 
public reactions to crisis, this exploratory research analyzed big data taken from social media posts that were found to include brands in the cereals industry and crisis-related terms during the crisis. For analysis of the data, we used natural language processing (NLP) by employing a combination of n-gram frequencies and bag-of-words (BoW) techniques. This combination was employed in order to identify latent themes and develop variables for statistical purposes [26].

The rest of the paper is organized as follows: the literature review describes the theoretical background of this study, focusing on public reactions to organizational crisis and stakeholders and crisis. Next, the methodology section describes the background of the Unilever-Telma 2016 crisis, the data collection and the corpus analysis procedure. In the following section, the results and consequent models are detailed. Finally, the models are discussed, followed by conclusions and contribution for theory and practice.

\section{Literature Review}

\subsection{Public Reactions to Organizational Crisis}

An organizational crisis can be defined as a considerable threat to organizational operations or reputations with potential negative consequences for stakeholders and/or the organization if not handled properly [25]. Situational crisis communication theory (SCCT) aims to provide organizations with guidelines for how to respond to various public reactions to crisis according to crisis types. Moreover, this theory assesses the impact of the crisis on the organization's long-term reputation [11]. SCCT is based on attribution theory, which is an umbrella term that describes and explains the way people assign causes to experienced events, accounting for emotional experiences and subsequent behaviors. According to this theory, people differ in their reactions to events in a variety of aspects. The locus of control dimension states that reaction is based on the interpretation of the cause of events-whether caused by people's own action (internal locus of control) or factors beyond their control (external locus of control) $[27,28]$.

Attribution of responsibility is not the only factor that explains the reputation threat to organizations. Recent research has suggested that the degree of crisis offensiveness (i.e., public subjective evaluation of the action that caused the crisis as a wrong action) may also explain the degree of reputational threat that emerged as a result of the crisis [29,30]. From another point of view, public evaluation of a crisis as a wrong action may also be explained by social contract theory (SCT) [31]. This theory implies that there is an unwritten social contract between business and consumers (or society) that implies normative ethics. This implicit contract stems from the interdependence between business and society. Scholars have stressed the role of the social contract as a form of moral guidance for business ethics that requires adjustments based on local community rules [32]. Perceived public offensiveness, the feeling of breaching a social contract, and attribution of responsibility are now expressed and shared online because of the rapid adoption of social media [33,34].

Much of the crisis-related public-centered research on social media has focused on consumer emotions [35]. For instance, Lachlan et al. [5] examined Twitter content after a crisis, revealing that most tweets contained affective orientation rather than actionable information. Brynielsson et al. [14] emphasized the importance of monitoring and collecting data on public use of social media during a crisis in order to gather important information about the crisis and understand its scope. They offered a tool based on machine learning in order to visualize emotional trends (anger, fear, and positive emotions) expressed in reactions to crisis-related announcements on Twitter. Vignal and Barki [15] suggested four emotional affects of publics: sympathy, sadness, fright and anger.

This background suggests that talk about a crisis on social media not only includes talk about the response of the organization in crisis and attribution of blame but incorporates other issues, such as public feelings and concerns, moral issues, and other issues concerning the relationship between business and society. Consequently, the first research question was:

RQ1: What are the most frequent issues raised by the public while addressing a crisis? 


\subsection{Stakeholders and Crisis}

From the public relations standpoint, the terms audiences, publics, and stakeholders are often used as alternatives to describe individuals that are affected (directly or indirectly) by a crisis and perceived by under-crisis organizations as message receivers [36]. Another approach divides stakeholders who are affected by crisis into internal stakeholders, such as managers and employees, and external stakeholders, which include diverse audiences such as the public and the media [37]. However, in strategic management studies, stakeholders are defined as organizations and or/individuals and groups that affect or are affected by the organization's conduct [38]. These stakeholders may be consumers, employees, competitors, suppliers, governments, special-interest groups (such as environmentalists), the media, investors (such as shareholders), and so on [39]. Consequently, stakeholder analysis is concerned with analyzing the relative importance of each group of stakeholders based on their interest in the organization and their power to affect its performance [40,41]. Thus, the context of this research, audiences were understood as message receivers, publics as groups of audiences, and stakeholders as all organizations and people (including publics) that are affected by a crisis and can affect the under-crisis organization.

Only a few previous studies have paid attention to the effect of a product crisis on stakeholders. Ji and Kim [17] showed that the government may be a stakeholder during a product crisis when highly involved consumers demand government regulatory intervention. Competitors have also been mentioned as stakeholders during crises, as they may be also damaged by a crisis that is perceived as a category crisis $[18,20]$ or see the crisis as an opportunity if it has negative spillover only within the same brand family and not to competitor brands [42,43]. Considering these studies, it was assumed that both the under-crisis organization and other various stakeholders may be involved in issues raised by the public during a crisis. Hence, the second research question:

RQ2: Who are the stakeholders involved in the issues raised by the public while discussing a crisis on social media?

Moreover, given a variety of issues raised by the public on social media, and the aim of attribution theory to describe and explain the way people assign causes to events they experience, it would be helpful to discover the connection between issues that the public experiences and shares. Thus, the third research question:

RQ3: What are the relationships between stakeholders and issues raised by the public?

As explained in the next section, this study's research questions were more likely to be answered by the automated content analysis technique used in the current research, as this technique monitored all talk about crisis in social media during the relevant time period.

\section{Methodology}

A data mining procedure was utilized on data collected on social media sites by monitoring discussions of the Unilever-Telma crisis of 2016.

\subsection{Background of the Unilever-Telma 2016 Crisis}

Unilever is a multinational brand, while Telma is an Israeli food brand established in 1947. However, the latter has been owned by the Unilever corporation in Israel (Unilever Israel) since 2000. The Unilever-Telma crisis was chosen for the current study because it is an instructive example of deficient corporate social responsibility (CSR) and crisis response strategy. In other words, it is a good example of poor crisis management $[25,29,30,44]$ that persisted for a relatively long period of time. The crisis started with bacteria pollution, to which the company responded with denial, apology, another pollution, evasion of responsibility, and only at the end an apologizing campaign (see full description below). Another reason for choosing this crisis was that food pollution caused by human error followed by a product recall (as in the case of the current study) was noted as one of 13 crisis types that are commonly perceived as offensive [45].

The Salmonella bacteria pollution found in Unilever-Telma cereals evolved into a crisis over multiple phases. Phase 1-Denial: On 27 July 2016, a shortage in Unilever-Telma 
Cornflakes and Deli-Pecan cereal products was reported by retailers and described in news channels. Unilever refused to explain the shortage. A day later, news channels revealed that the distribution of these products was stopped because of suspicion of Salmonella bacteria pollution in the production lines, with the company not reporting this to the Health Ministry or the public. Only then did Unilever admit the problem and announce that the polluted products were exterminated in the factory and were not distributed to the market. Phase 2-Apology: On 31 July, Unilever started an ad campaign apologizing and trying to calm their consumers down, although the company nevertheless suffered a 30\% drop in sales. Phase 3-Continued Pollution: On 2 August, Unilever revealed that another cereal brand was polluted. Phase 4-Admission of Problem: On 4 August, Unilever admitted to the public that other products were polluted with Salmonella and announced a recall. Phase 5-Evasion of Responsibility: On 6 August, Unilever claimed that one of its employees switched the barcode stickers on the products, causing the distribution of polluted products in one area of the country. Phase 6-End of Crisis: On 5 September, "back to school" discounts raised product sales again.

Based on Coombs's [46] classification of crisis types, the Unilever-Telma crisis matched the "preventable cluster" crisis type, since the company did not take the appropriate actions to prevent the crisis. Hence, this cluster of crises produced a strong attribution of crisis responsibility toward the company [45].

\subsection{Data Collection}

The data was collected by Vigo, a social media monitoring and analysis company that uses a data collection algorithm to collect, in real time, items from across the Internet and across platforms, including Facebook, Instagram, Twitter, YouTube, forums, and blogs. Out of the approximately 23,000 social media posts on cereals during the crisis period (27 July to 27 August 2016) that Vigo's algorithm collected, 9929 posts were extracted by Vigo to include both brand names from the cereal industry and crisis-related terms (e.g., crisis, the crisis, the episode, the event, the damage, the case, the problem, salmonella, bacteria). Most of the posts were from Facebook $(74 \%)$, with the rest from Twitter (16\%), different forums $(4 \%)$, blogs ( $3 \%)$, and other sources $(3 \%)$.

\subsection{Procedure-Corpus Analysis}

Corpus analysis allows quantitative textual analysis of large of text (such as social media posts) and focus on selected features of the text, or even many features of the text simultaneously. It is a semiautomated analysis of patterns in a specified text collection. The semiautomated programs allow detecting selected keywords (in the current study, keywords such as related brand names and crisis-related terms such as salmonella, bacteria, crisis, etc.). Next, it allows the researcher to investigate characteristic patterns between those keywords and expressions that appear frequently and in proximity in the social media posts $[47,48]$. In the current case, it was programmed to look for words such as negligence, apologize, not reliable, etc. (Table 1). Quantitative linguistic analysis of language is more than just counting appearances of key word and nearby words, but it allows the researcher to create variables out of texts and perform statistical analysis of the correlations between these variables [49].

The automated content analysis technique was utilized in the current research, based on natural language processing (NLP). First, n-gram frequencies were generated, with n-grams capturing words or tokens that appeared together in the textual corpus with a certain frequency. N-gram language models are widely used in language processing applications and typically give good ranking results [50]. Next, the bag-of-words (BoW) model was used. The BoW approach was adapted from NLP and information retrieval [51] as the classic and most popular form of document representation because of its simplicity and general applicability [52]. According to this technique, a collected set of keywords was explored in all the corpus documents. The keywords were assigned a value indicating 
their frequency in the document and a binary representation of whether they did or did not appear.

Table 1. Variable definition, related words, and examples.

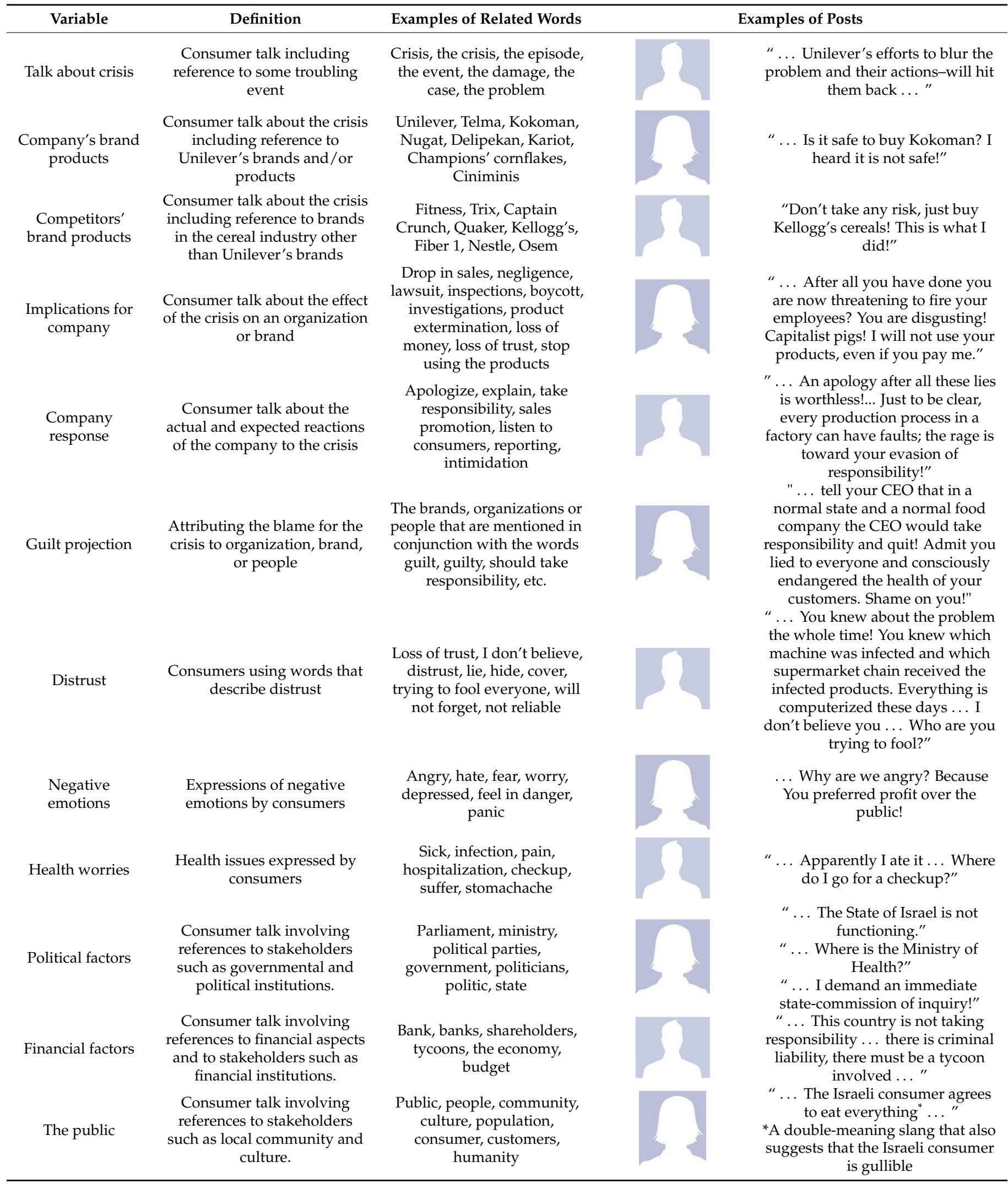


Following this approach, words with the highest frequency were compiled into groups and employed as the research variables. As in past studies that employed the BoW approach [53], frequencies of groups of words were then summed to create variables. Although the computer-program-analyzed content is dependent on the researcher's subjective decisions concerning variables, statistical NLP allows researchers to observe phenomena and draw valuable conclusions from a large amount of text, which is not a simple task in the age of electronic communication and big data (Manning et al., 1999). Moreover, analyzing all posts avoids a common obstacle encountered by disaster and crisis studies-generating randomized samples [54].

\section{Results}

Computerized content analysis enabled the use of groups of related words to facilitate identification of the main issues expressed by the public when discussing the crisis. This procedure produced a series of variables related to different active players in the productindustry environment. From this list, the researchers selected the most prominent variables (that were consecutively treated in the discussions during the relevant time period). The selection process of the related words and the labeling of the variables was conducted in two main stages: 1 ) the three researchers independently screened the lists of repeated words and their context and grouped them into labeled variables; 2) the researchers compared their lists and discussed their findings in order to minimize researcher subjectivity and resolve any discrepancies [55-57]. Variables that were identified as related to the discussion of crisis and the involved brands were selected as representatives of the main issues expressed by the public. Table 1 specifies the selected variables, their definitions, examples of words related to the variables, and examples of posts related to these issues.

Next, the variables (the main issues expressed by the public), the brand under crisis, and the industry-related brands were correlated to examine the relationships among them (Table 2 shows the correlation matrix). The results show that the crisis was significantly related to the brand under crisis $(\mathrm{r}=0.11, p<0.01)$ but not to competing brands $(\mathrm{r}=0.01$, $p>0.01)$.

Table 2. Correlation Matrix.

\begin{tabular}{|c|c|c|c|c|c|c|c|c|c|c|c|}
\hline Variables & 1 & 2 & 3 & 4 & 5 & 6 & 7 & 8 & 9 & 10 & 11 \\
\hline $\begin{array}{l}\text { 1. Talk about } \\
\text { crisis }\end{array}$ & 1 & & & & & & & & & & \\
\hline $\begin{array}{l}\text { 2. Company's } \\
\text { brand products }\end{array}$ & $0.11 * *$ & 1 & & & & & & & & & \\
\hline $\begin{array}{l}\text { 3. Competitors' } \\
\text { brand products }\end{array}$ & 0.01 & 0.02 & 1 & & & & & & & & \\
\hline $\begin{array}{l}\text { 4. Company } \\
\text { response }\end{array}$ & $0.15^{* *}$ & 0.06 ** & 0.00 & 1 & & & & & & & \\
\hline $\begin{array}{l}\text { 5. Implications } \\
\text { for company }\end{array}$ & $0.30 * *$ & $0.06^{* *}$ & 0.02 & $0.31^{* *}$ & 1 & & & & & & \\
\hline $\begin{array}{l}\text { 6. Guilt } \\
\text { projection }\end{array}$ & $0.27 * *$ & $0.19^{* *}$ & $0.02 *$ & $0.14^{* *}$ & $0.32 * *$ & 1 & & & & & \\
\hline 7. Distrust & $0.12 * *$ & $0.05^{* *}$ & 0.01 & $0.38^{* *}$ & $0.18^{* *}$ & $0.11^{* *}$ & 1 & & & & \\
\hline $\begin{array}{l}\text { 8. Negative } \\
\text { emotions }\end{array}$ & $0.24^{* *}$ & $0.08^{* *}$ & 0.01 & $0.43^{* *}$ & $0.33^{* *}$ & 0.02 & $0.31 * *$ & 1 & & & \\
\hline 9. Health worries & $0.22 * *$ & $0.03 * *$ & $0.03^{* *}$ & $0.24 * *$ & $0.41 * *$ & $0.12 * *$ & $0.20 * *$ & $0.44^{* *}$ & 1 & & \\
\hline $\begin{array}{l}\text { 10. Political } \\
\text { factors }\end{array}$ & $0.06^{* *}$ & $-0.04^{* *}$ & 0.01 & $0.17^{* *}$ & $0.30 * *$ & $0.09^{* *}$ & $0.15^{* *}$ & -0.01 & $0.09 * *$ & 1 & \\
\hline $\begin{array}{l}\text { 11. Financial } \\
\text { factors }\end{array}$ & $0.22 * *$ & -0.02 & 0.02 & $0.25^{* *}$ & $0.26^{* *}$ & $0.02 *$ & $0.12 * *$ & $0.06^{* *}$ & $0.15^{* *}$ & $0.38^{* *}$ & 1 \\
\hline 12. The public & $0.37 * *$ & $0.09 * *$ & $0.08^{* *}$ & $0.24 * *$ & $0.56^{* *}$ & $0.33^{* *}$ & $0.21 * *$ & $0.34 * *$ & $0.39 * *$ & $0.38^{* *}$ & $0.40 * *$ \\
\hline
\end{tabular}

Notes: $\mathrm{N}=9929$; ${ }^{*} p<0.05$; ** $p<0.001$ (the null hypothesis was "no relationships" among variables).

To further examine the relationships among the issues, the variables were entered into a regression equation using structural equation modeling (SEM). This process learns and corroborates previous research using simulations within agent-based modeling. The results indicated that the media played a key role in speeding alarming information and 
that the media offered potentially valid sources of information to reduce uncertainty [58]. Two models were formulated, one for industry-based issues and one for stakeholder issues. Following the procedure proposed by Bagozzi and Edwards [59], several alternative models were analyzed, and the models that showed the best fit were kept as the research models.

SEM was used to test the model's goodness of fit. Model fit was evaluated using normed fit index (NFI), comparative fit index (CFI), root mean square error of approximation (RMSEA), and $\chi^{2}$ value/DF ratio [60]. For NFI and CFI, cutoff values of $>0.95$ indicateacceptable fit; for RMSEA, value of $<0.06$; and for $\chi^{2}$ value/DF, value of $\leq 2$ [61].

In the industry-based model, the path analysis results showed that the overall fit statistics (goodness-of-fit measures) exhibited an acceptable level of fit $\left(\chi^{2}\right.$ value $=21.10(11)$, $\chi^{2} / \mathrm{Df}<2, p=0.03 ; \mathrm{CFI}=0.999 ; \mathrm{NFI}=0.998$; and RMSEA $\left.=0.010\right)$, indicating that the path model was valid. The path model, regression standardized coefficients, and their significance are depicted in Figure 1.

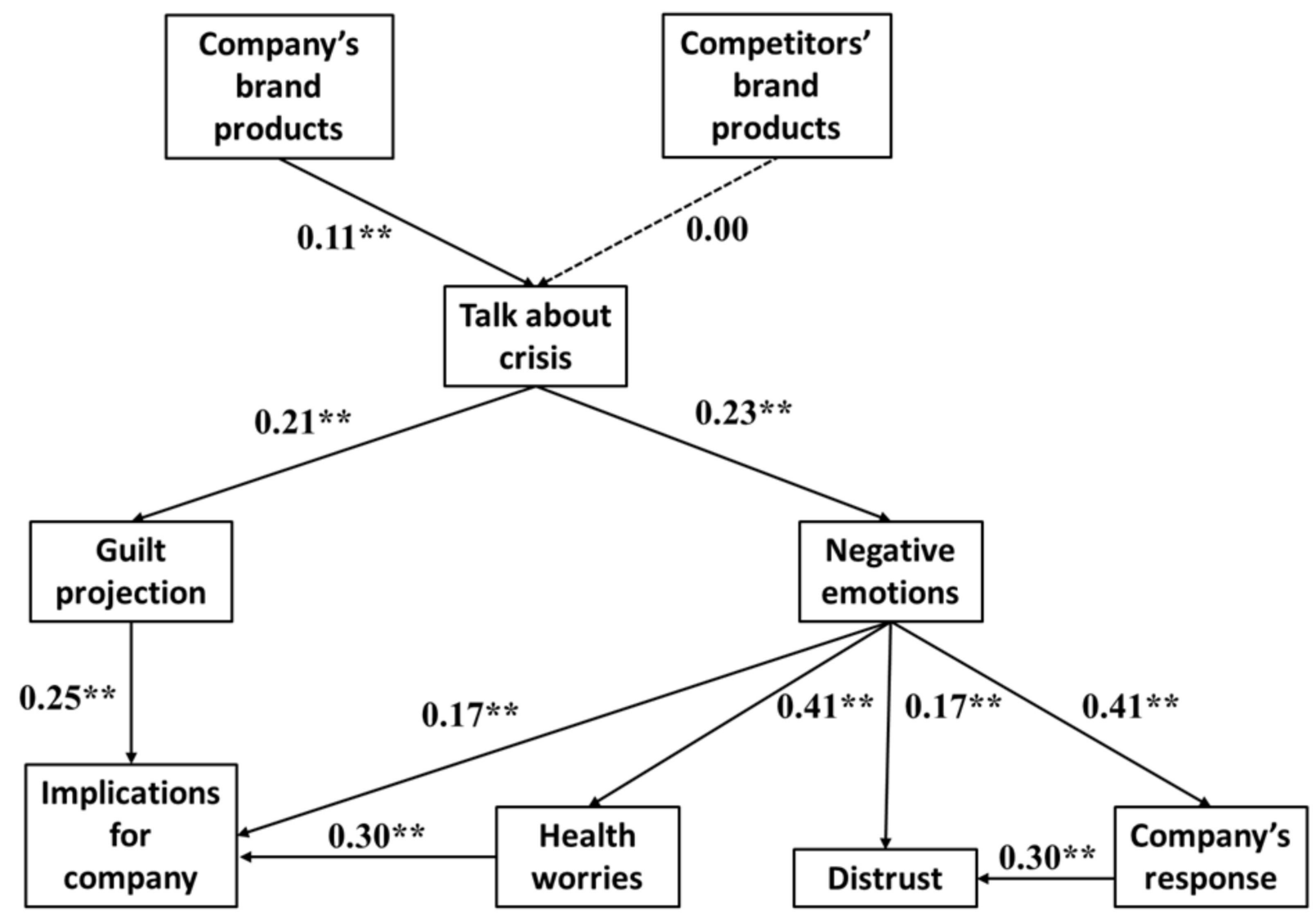

Figure 1. An industry-based model—path analysis results (path parameters are standardized parameter estimates; ${ }^{* *}, p<0.01$ ).

Figure 1 displays the most frequently raised issues. Considering the huge sample size, only relationships that demonstrated satisfactory effect size are treated [62]. It demonstrates that posts about the crisis were significantly related to the brands involved in the crisis $(\beta=0.11, p<0.01)$ rather than their competitors $(\beta=0.00, p>0.1)$.

Figure 1 further depicts two discourse paths. The first path emerged from the direct positive relationship between talk about the crisis and guilt projection $(\beta=0.21, p<0.01)$. Consequently, guilt projection was related to implication for the company $(\beta=0.25, p<0.01)$ and mediated the indirect relationship between talk about the crisis and implication for the company $(\beta=0.12,95 \%$ CI: $0.11-0.13, p<0.05)$. The model further showed a second path that emerged from the direct relationship between talk about the crisis and negative emotions $(\beta=0.23, p<0.01)$. Negative emotions had positive relationships with the company's response $(\beta=0.41, p<0.01)$, distrust $(\beta=0.17, p<0.01)$, health worries $(\beta=0.41, p<0.01)$, and implications for the company $(\beta=0.17, p<0.01)$. Negative emotions mediated the 
indirect relationships between talk about the crisis and the company's response ( $\beta=0.09$, 95\% CI: $0.08-0.10, p<0.05)$, distrust $(\beta=0.07,95 \%$ CI: $0.06-0.08, p<0.05)$, and health worries $(\beta=0.09,95 \%$ CI: $0.08-0.10, p<0.05)$. Also, the company's response was related to distrust $(\beta=0.30, p<0.01)$ and health worries were related to implications for the company $(\beta=0.30, p<0.01)$. Table 3 shows the variables' direct relationships and relevant statistical measures.

Table 3. Variables' direct relationships.

\begin{tabular}{|c|c|c|c|c|c|c|}
\hline & \multirow{2}{*}{$\begin{array}{c}\begin{array}{c}\text { Standardized } \\
\text { Effect }\end{array} \\
\text { Direct }\end{array}$} & \multirow{2}{*}{$\begin{array}{l}\text { Effect Size } \\
\text { (F Square) }\end{array}$} & \multicolumn{4}{|c|}{ Regression Weights } \\
\hline & & & Estimate & S.E. & C.R. & $\mathbf{P}$ \\
\hline $\begin{array}{l}\text { Company's } \\
\text { brand products } \\
\quad \rightarrow \text { Crisis }\end{array}$ & 0.114 & 0.013 & 0.164 & 0.014 & 11.686 & 0.000 \\
\hline $\begin{array}{l}\text { Competitors' } \\
\text { brand products } \\
\rightarrow \text { Crisis }\end{array}$ & 0.005 & 0.000 & 0.032 & 0.014 & 0.506 & 0.613 \\
\hline $\begin{array}{l}\text { Crisis } \rightarrow \text { Guilt } \\
\text { projection }\end{array}$ & 0.207 & 0.045 & 0.326 & 0.015 & 21.366 & 0.000 \\
\hline $\begin{array}{l}\text { Crisis } \rightarrow \\
\text { Negative } \\
\text { emotions }\end{array}$ & 0.231 & 0.056 & 0.457 & 0.019 & 23.555 & 0.000 \\
\hline $\begin{array}{l}\text { Guilt projection } \\
\rightarrow \text { Implications } \\
\text { for company }\end{array}$ & 0.252 & 0.068 & 0.285 & 0.010 & 29.023 & 0.000 \\
\hline $\begin{array}{l}\text { Negative } \\
\text { emotions } \rightarrow \\
\text { Company's } \\
\text { response }\end{array}$ & 0.415 & 0.208 & 0.110 & 0.002 & 44.517 & 0.000 \\
\hline $\begin{array}{c}\text { Negative } \\
\text { emotions } \rightarrow \\
\text { Distrust }\end{array}$ & 0.173 & 0.030 & 0.043 & 0.003 & 16.723 & 0.000 \\
\hline $\begin{array}{c}\text { Negative } \\
\text { emotions } \rightarrow \\
\text { Health worries }\end{array}$ & 0.407 & 0.199 & 1.372 & 0.031 & 44.274 & 0.000 \\
\hline $\begin{array}{l}\text { Negative } \\
\text { emotions } \rightarrow \\
\text { Implications for } \\
\text { company }\end{array}$ & 0.166 & 0.028 & 0.149 & 0.009 & 17.213 & 0.000 \\
\hline $\begin{array}{l}\text { Company's } \\
\text { response } \rightarrow \\
\text { Distrust }\end{array}$ & 0.299 & 0.098 & 0.284 & 0.010 & 29.542 & 0.000 \\
\hline $\begin{array}{l}\text { Health worries } \\
\rightarrow \text { Implications } \\
\text { for company }\end{array}$ & 0.298 & 0.098 & 0.079 & 0.003 & 31.062 & 0.000 \\
\hline
\end{tabular}

In the stakeholder model, the path analysis results showed that the overall fit statistics (goodness of fit measures) exhibited an acceptable level of fit $\left(\chi^{2}\right.$ value $=13.07$ (18), $\chi^{2} / \mathrm{Df}<2, p=0.11 ; \mathrm{CFI}=1.000 ; \mathrm{NFI}=0.999$; and RMSEA $\left.=0.008\right)$, indicating that the path model was valid. The path model, regression standardized coefficients, and their significance are depicted in Figure 2. 


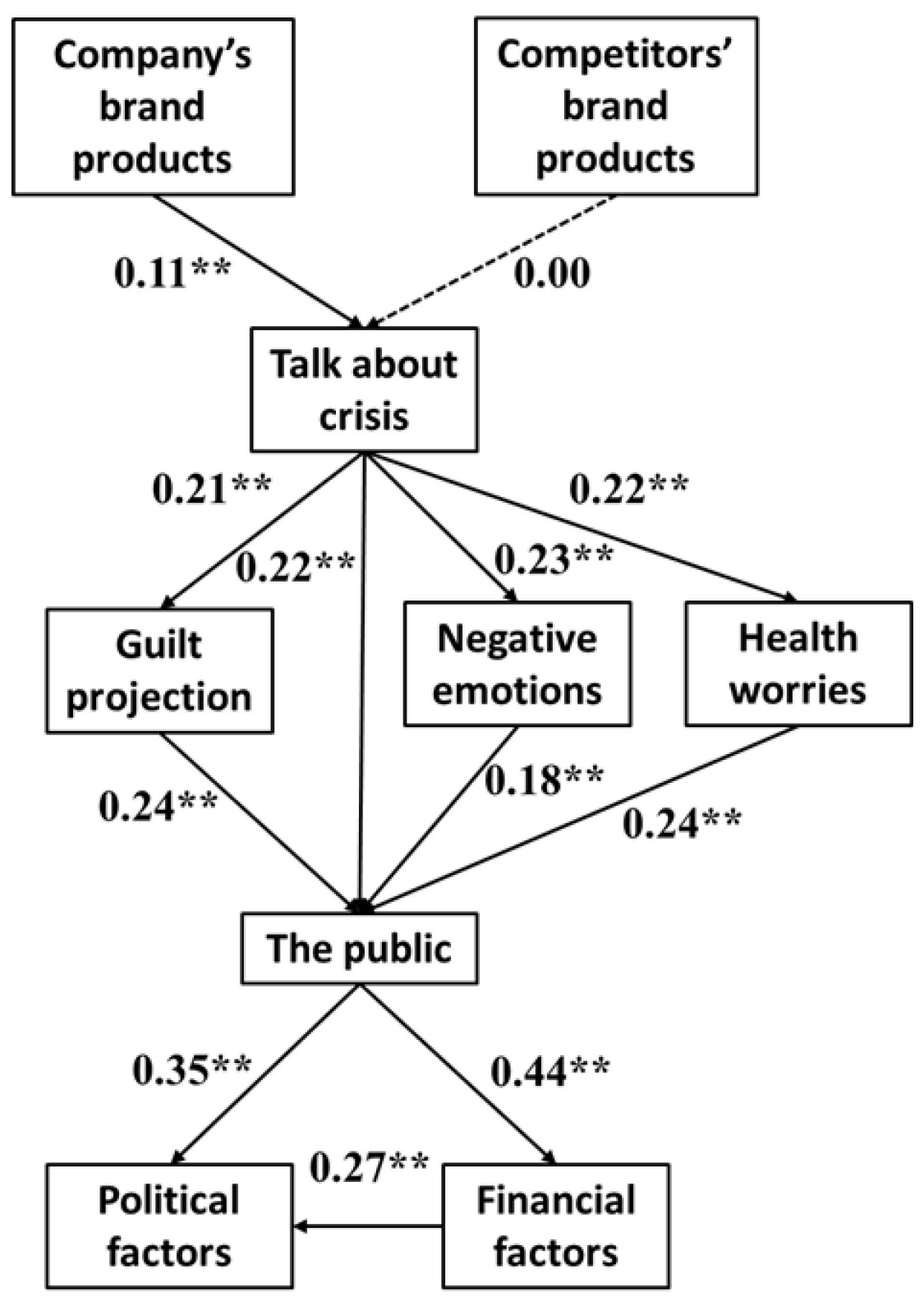

Figure 2. Stakeholder model-path analysis results (path parameters are standardized parameter estimates; $\left.{ }^{* *}, p<0.01\right)$.

Figure 2 shows that talk about crisis was directly related to talk about the public $(\beta=0.22, p<0.01)$. However, the relationships between talk about the crisis and guilt projection $(\beta=0.21, p<0.01)$, negative emotion $(\beta=0.18, p<0.01)$, and health worries $(\beta=0.24, p<0.01)$ mediated an additional indirect relationship between talk about the crisis and talk about the public $(\beta=0.14 ; 95 \%$ CI: $0.13-0.15, p<0.01)$. These indicated a total effect of $\beta=0.360$. Talk about the public related to talk about financial factors $(\beta=0.44, p<0.01)$ and political factors $(\beta=0.35, p<0.01)$, which mediated their indirect relationships with talk about the crisis $(\beta=0.16,95 \%$ CI: $0.15-0.17, p<0.05$ and $\beta=0.17$, $95 \%$ CI: $0.16-0.18, p<0.05$, respectively). Additionally, talk about financial factors was related to talk about political factors $(\beta=0.27, p<0.01)$. Table 4 exhibits the direct variable relationships and relevant statistical measures. 
Table 4. Variables' direct relationships.

\begin{tabular}{|c|c|c|c|c|c|c|}
\hline & \multirow{2}{*}{$\begin{array}{c}\begin{array}{c}\text { Standardized } \\
\text { Effect }\end{array} \\
\text { Direct }\end{array}$} & \multirow{2}{*}{$\begin{array}{l}\text { Effect Size } \\
\text { (F Square) }\end{array}$} & \multicolumn{4}{|c|}{ Regression Weights } \\
\hline & & & Estimate & S.E. & C.R. & $\mathbf{P}$ \\
\hline $\begin{array}{l}\text { Crisis } \rightarrow \text { Guilt } \\
\text { projection }\end{array}$ & 0.207 & 0.045 & 0.326 & 0.015 & 21.365 & 0.000 \\
\hline $\begin{array}{l}\text { Crisis } \rightarrow \text { The } \\
\text { public }\end{array}$ & 0.218 & 0.050 & 0.446 & 0.018 & 24.680 & 0.000 \\
\hline $\begin{array}{l}\text { Crisis } \rightarrow \\
\text { Negative } \\
\text { emotions }\end{array}$ & 0.231 & 0.056 & 0.457 & 0.019 & 23.583 & 0.000 \\
\hline $\begin{array}{c}\text { Crisis } \rightarrow \text { Health } \\
\text { worries }\end{array}$ & 0.222 & 0.052 & 1.481 & 0.065 & 22.656 & 0.000 \\
\hline $\begin{array}{l}\text { Guilt projection } \\
\rightarrow \text { The public }\end{array}$ & 0.243 & 0.058 & 0.315 & 0.011 & 28.372 & 0.000 \\
\hline $\begin{array}{c}\text { Negative } \\
\text { emotions } \rightarrow \text { The } \\
\text { public }\end{array}$ & 0.177 & 0.032 & 0.182 & 0.010 & 18.841 & 0.000 \\
\hline $\begin{array}{l}\text { Health worries } \\
\rightarrow \text { The public }\end{array}$ & 0.237 & 0.059 & 0.073 & 0.003 & 25.292 & 0.000 \\
\hline $\begin{array}{l}\text { Public } \rightarrow \\
\text { Financial factors }\end{array}$ & 0.437 & 0.236 & 0.296 & 0.007 & 40.286 & 0.000 \\
\hline $\begin{array}{c}\text { Public } \rightarrow \\
\text { Political factors }\end{array}$ & 0.350 & 0.140 & 0.220 & 0.007 & 32.254 & 0.000 \\
\hline $\begin{array}{c}\text { Financial factors } \\
\rightarrow \text { Political } \\
\text { factors }\end{array}$ & 0.270 & 0.079 & 0.251 & 0.009 & 27.421 & 0.000 \\
\hline
\end{tabular}

\section{Discussion and Conclusions}

Based on SCCT as well as public-centered and social-mediated crisis communication studies, our findings complement a public-centered focus on crisis from industry-based to stakeholder levels and extend investigation into their interrelationships. Furthermore, the study emphasizes the importance of sustainable corporate behavior, which, in time of crisis, should include a wide spectrum of stakeholders $[39,63]$ that could be affected by the negative spillover effect.

The crisis posts were significantly related to under-crisis brand products (Unilever's cereals) and issues such as guilt projection, negative feelings, and health worries. The negative posts effectively skipped the competitor brand products, affirming that in time of crisis in the food industry, consumers tend to think in terms of brand and not categories [42]. However, the most interesting and unique finding was the scope of the issues raised by the public as a reaction to the crisis. The issues raised, the relationships between them, and their scope were articulated in two comprehensive frameworks.

The first framework focused on talk about the crisis in conjunction with the undercrisis brand products. According to motivational psychology theory [64], causal beliefs are the basis of action tendencies, with causal knowledge also generating emotions. Thus, according to this theory, the belief that Unilever is the main source to be blamed for the crisis predicts the negative feelings and behavior of the consumers. This explains the public's justified reactions, presented in Figure 1, involving the role of guilt projection (causal knowledge representing rational thinking) and negative emotions (gathering emotional feelings) on implications for the company (predicted behavior of the public toward the company). 
Interestingly, this framework could also be split into two trajectories: one that stemmed from guilt projection and another from negative emotions. As described in attribution theory, guilt projection can be seen as a more "rational" path to implications for the company. Blaming the under-crisis organization as responsible for the event (i.e., internal locus of control) $[27,28]$ leads to a rationally justified reaction as reflected and expressed in the implications for company: boycotts, lawsuits, etc. The second trajectory, starting from negative emotions, is more complex and emotional. It demonstrates how negative emotions are connected directly to implications for company and indirectly through health worries. Interestingly, distrust was connected not to guilt projection but to negative emotions and company's response. Thus, if the public is emotionally distressed, it consequently does not believe the under-crisis organization, mostly due to its unacceptable response-not taking responsibility for the crisis.

As for the second framework (Figure 2), significant relationships were found between issues that were related directly not to the under-crisis company but to the macro environment of the crisis, namely, stakeholders such as the public, political factors, and financial factors. Talk about the crisis involves the public-individual consumers, the group affected by the crisis, and local consumer culture. The relationship between talk about the crisis and the public also involved negative public feelings, along with health worries and thoughts about the responsible parties, reflecting the various reactions to the crisis. As a result, the public blamed itself as one of the stakeholders responsible for preventing the crisis, and this blame spilled over to other stakeholders, such as the government and economic system. These findings can be explained by social contract theory.

According to Donaldson's [31] philosophical approach to social contract theory, the ethical contract between government and society is similar to the contract between business and consumers. The findings of the current case demonstrate that when businesses breach this social contract, from the public's point of view, the government and its institutions are expected to enforce the contract and punish the transgressor. These findings add to studies on the attribution of responsibility by demonstrating how the locus of control dimension, based on public interpretation of the agent responsible for managing the crisis, can be attributed to others in addition to the organization with direct control over the crisis $[27,28]$.

These findings also represent the web of relationships between the organization in crisis and stakeholders mutually influenced by the crisis $[65,66]$. It can be assumed that the high crisis level (in the Unilever case, a health threat caused by food pollution combined with both denial and evasion of responsibility) not only caused a high degree of reputational threat to the under-crisis organization $[29,30,45]$ but also to its stakeholders. From this point of view, and following Donaldson and Dunfee's [32] view on social contract theory, organizations should assume an unwritten contract not only with their consumers but with all stakeholders. This approach is supported by CSR theory, which assumes that organizations have ethical and moral obligations to all stakeholders $[67,68]$.

Since most research on public reactions to crisis on social media has been concerned with the effectiveness of organizational communication, scant attention has been given to reactions that are not directed toward the involved firm. Thus, the implications of the current research for practice emphasize the need for broader crisis communication strategies in order to handle reputational damage caused by a wide range of attribution of responsibilities perceived by the public. Since attribution of responsibility might extend to a variety of stakeholders, it is likely that stakeholders that find themselves under attack by the public will take actions to minimize this reputational damage. This "second-order" attribution of responsibility should be addressed strategically with regard to the correct response strategy and actions. These actions can target the organization first involved in the crisis. Thus, situational crisis communication theory should be extended to include these second-order attributions, and the prominence and antecedents of these attributions during and after crisis should be further investigated in future studies. 
Socially, this research gives voice to issues that concern the public during crises, both as individuals and as a community. Attributing responsibility to society itself by members of the same society for not doing enough to stand up for their rights and demand corporate accountability is the material from which social protests are made. This phenomenon is certainly culture-dependent [34] and calls for comparative cultural studies.

A limitation of the technique used in the current study for analysis of the information is that grouping of words may have been liable to subjectivity. However, reducing opinions on textual content to specific keywords reduced the subjectivity range. Furthermore, agreement among three researchers on groups of keywords enhanced the objectivity. Compared to the automated or semiautomated content analysis techniques that we employ, manual content analysis using a coding book is more subjective by nature and liable to researcher bias [69]. In addition, for large corpuses, automated content analysis outperforms manual content analysis in terms of required analysis resources and the capability to detect latent themes [53].

While there are different techniques in NLP, n-grams are the most commonly used feature extraction method in text classification [70] and the base of language modeling [71]. $\mathrm{N}$-grams' key advantages are their language independence and simplicity [72]. In addition, BoW is the most widely used text representation method [73]. Therefore, the combination of N-Gram and BOW offers a grounded method.

The current research was exploratory, using an innovative data mining technique based on a single case study. Nevertheless, we expect transferability of the results to other crises in the food industry or even to other industries where the consequences of crises undermine sustainability. For greater generalization, further research should examine the results of this study in regard to other cases of crisis, recognizing the variety of stakeholders that might be involved in the spillover effect. Additionally, further research should integrate sentiment analysis to address social media users' spectrum of feelings [58]. Besides that, future research on data regarding consumer purchase behavior during and after crisis, such as sales reports, may enrich the findings and conclusions.

Author Contributions: Conceptualization, D.Z.-S. and S.L.; methodology, D.Z.-S., S.L. and E.E.; software, E.E.; validation, S.L. and E.E.; formal analysis, D.Z.-S., S.L. and E.E.; investigation, D.Z.-S., S.L. and E.E.; resources, D.Z.-S. and S.L.; data curation, E.E.; writing-original draft preparation, D.Z.-S., S.L. and E.E.; Writing-review \& editing, D.Z.-S., S.L. and E.E.; visualization, D.Z.-S., S.L. and E.E.; Project administration, D.Z.-S.; All authors have read and agreed to the published version of the manuscript.

Funding: This research received no external funding.

Institutional Review Board Statement: Not applicable.

Informed Consent Statement: Not applicable.

Data Availability Statement: Not applicable.

Conflicts of Interest: The authors declare no conflict of interest.

\section{References}

1. Bakos, L.; Dumitrașcu, D.D.; Harangus, K. Human factor preparedness for decentralized crisis management and communication in cyber-physical systems. Sustainability 2019, 11, 6676. [CrossRef]

2. Ayman, U.; Kaya, A.K.; Kuruç, Ü.K. The impact of digital communication and PR models on the sustainability of higher education during crises. Sustainability 2020, 12, 8295. [CrossRef]

3. Mascareño, A.; Henríquez, P.; Billi, M.; Ruz, G. A twitter-lived red tide crisis on Chiloé Island, Chile: What can be obtained for social-ecological research through social media analysis? Sustainability 2020, 12, 8506. [CrossRef]

4. Cheng, Y.; Cameron, G. The status of social-mediated crisis communication (SMCC) research. In Social Media and Crisis Communication; Austin, L., Jin, Y., Eds.; Routledge: New York, NY, USA, 2017; pp. 9-20.

5. Lachlan, K.; Spence, P.; Lin, X.; Najarian, K.; Del Greco, M. Social media and crisis management: CERC, search strategies, and twitter content. Comput. Hum. Behav. 2016, 54, 647-652. [CrossRef]

6. Borden, J.; Zhang, X.A.; Hwang, J. Improving automated crisis detection via an improved understanding of crisis language: Linguistic categories in social media crises. J. Conting. Crisis Manag. 2020, 28, 281-290. [CrossRef] 
7. Kersten, J.; Klan, F. What happens where during disasters? a workflow for the multifaceted characterization of crisis events based on twitter data. J. Conting. Crisis Manag. 2020, 28, 262-280. [CrossRef]

8. Sheiner, D.Z.; Lahav, T. Managing marketing communications. Qual. Mark. Res. Int. J. 2020, 23, 363-379. [CrossRef]

9. Bryl, Ł.; Majewska, J.; Truskolaski, S. Effects of the Covid-19 pandemic on sport, video game, and tourism industry: Sentiment analysis of press, internet articles, and Twitter data. In Towards the "New Normal" after COVID-19—A Post-Transition Economy Perspective; Mińska-Struzik, E., Jankowska Poznań, B., Eds.; PUEB Press: Al. Niepodległości, Poland, 2021; pp. 137-151.

10. Reuter, C.; Hughes, A.L.; Kaufhold, M.-A. Social media in crisis management: An evaluation and analysis of crisis informatics research. Int. J. Hum.-Comput. Interact. 2018, 34, 280-294. [CrossRef]

11. Coombs, W.T.; Holladay, S.J. How publics react to crisis communication efforts. J. Commun. Manag. 2014, 18, 40-57. [CrossRef]

12. Fraustino, J.D.; Liu, B.F. Toward more audience-oriented approaches to crisis communication and social media research. In Social Media and Crisis Communication; Austin, L., Jin, Y., Eds.; Routledge: New York, NY, USA, 2017; pp. 129-140.

13. Liu, B.F.; Fraustino, J.D. Beyond image repair: Suggestions for crisis communication theory development. Public Relat. Rev. 2014, 40, 543-546. [CrossRef]

14. Brynielsson, J.; Johansson, F.; Jonsson, C.; Westling, A. Emotion classification of social media posts for estimating people's reactions to communicated alert messages during crises. Secur. Inform. 2014, 3, 7. [CrossRef]

15. Lambret, C.V.; Barki, E. Social media crisis management: Aligning corporate response strategies with stakeholders' emotions online. J. Conting. Crisis Manag. 2018, 26, 295-305. [CrossRef]

16. Ma, L. How the interplay of consumer-brand identification and crises influences the effectiveness of corporate response strategies. Int. J. Bus. Commun. 2020. [CrossRef]

17. Ji, Y.; Kim, S. Crisis-induced public demand for regulatory intervention in the social media era: Examining the moderating roles of perceived government controllability and consumer collective efficacy. New Media Soc. 2019, 22, 959-983. [CrossRef]

18. Bala, R.; Bhardwaj, P.; Chintagunta, P. Pharmaceutical product recalls: Category effects and competitor response. Mark. Sci. 2017, 36, 931-943. [CrossRef]

19. Ackermann, F.; Eden, C. Strategic management of stakeholders: Theory and practice. Long Range Plan. 2011, 44, 179-196. [CrossRef]

20. Yu, T.; Lester, R.H. Moving beyond firm boundaries: A social network perspective on reputation spillover. Corp. Reput. Rev. 2008, 11, 94-108. [CrossRef]

21. Veil, S.R.; Dillingham, L.L.; Sloan, A.G. Fencing out the jones's: The development of response strategies for spillover crises. Corp. Reput. Rev. 2016, 19, 316-330. [CrossRef]

22. Ouyang, Z.; Yao, C.N.; Hu, X. Crisis spillover of corporate environmental misconducts: The roles of perceived similarity, familiarity, and corporate environmental responsibility in determining the impact on oppositional behavioral intention. Bus. Strat. Environ. 2020, 29, 1797-1808. [CrossRef]

23. Ingenhoff, D.; Buhmann, A.; White, C.; Zhang, T.; Kiousis, S. Reputation spillover: Corporate crises' effects on country reputation. J. Commun. Manag. 2018, 22, 96-112. [CrossRef]

24. Arbaa, O.; Varon, E. Turkish currency crisis-Spillover effects on european banks. Borsa Istanb. Rev. 2019, 19, 372-378. [CrossRef]

25. Coombs, W.T. Ongoing Crisis Communication: Planning, Managing, and Responding, 4th ed.; Sage Publications: Thousand Oaks, CA, USA, 2015.

26. Levy, I.; Eckhaus, E. Rape narratives analysis through natural language processing: Survivor self-label, narrative time span, faith, and rape terminology. Psychol. Trauma Theory Res. Pract. Policy 2020, 12, 635-642. [CrossRef] [PubMed]

27. Rotter, J.B. Generalized expectancies for internal versus external control of reinforcement. Psychol. Monogr. Gen. Appl. 1966, 80, 1-28. [CrossRef]

28. Shim, K.; Yang, S.-U. The effect of bad reputation: The occurrence of crisis, corporate social responsibility, and perceptions of hypocrisy and attitudes toward a company. Public Relat. Rev. 2016, 42, 68-78. [CrossRef]

29. Pan, L.Y.; Chen, K.H. A study on the effect of storytelling marketing on brand image, perceived quality, and purchase intention in ecotourism. Ekoloji 2019, 28, 705-712.

30. Page, T.G. Beyond attribution: Building new measures to explain the reputation threat posed by crisis. Public Relat. Rev. 2019, 45, 138-152. [CrossRef]

31. Donaldson, T. Corporations and Morality; Prentice Hill: Englewood Cliffs, NJ, USA, 1982.

32. Donaldson, T.; Dunfee, T.W. Ties that Bind: A Social Contracts Approach to Business Ethics; Harvard Business School Press: Boston, MA, USA, 1999.

33. Cheng, Y. How social media is changing crisis communication strategies: Evidence from the updated literature. J. Conting. Crisis Manag. 2018, 26, 58-68. [CrossRef]

34. Cheng, Y. The social-mediated crisis communication research: Revisiting dialogue between organizations and publics in crises of China. Public Relat. Rev. 2020, 46, 101769. [CrossRef]

35. Kydros, D.; Argyropoulou, M.; Vrana, V. A content and sentiment analysis of greek tweets during the pandemic. Sustainability 2021, 13, 6150. [CrossRef]

36. Marynissen, H.; Lauder, M. Stakeholder-focused communication strategy during crisis: A case study based on the brussels terror attacks. Int. J. Bus. Commun. 2019, 57, 176-193. [CrossRef]

37. Marsen, S. Navigating crisis: The role of communication in organizational crisis. Int. J. Bus. Commun. 2019, 57, 163-175. [CrossRef] 
38. Freeman, R.E. The politics of stakeholder theory: Some future directions. Bus. Ethic-Q. 1994, 4, 409-421. [CrossRef]

39. Lozano, R.; Suzuki, M.; Carpenter, A.; Tyunina, O. An analysis of the contribution of japanese business terms to corporate sustainability: Learnings from the "looking-glass" of the east. Sustainability 2017, 9, 188. [CrossRef]

40. Freeman, R.E.; Reed, D.L. Stockholders and stakeholders: A new perspective on corporate governance. Calif. Manag. Rev. 1983, 25, 88-106. [CrossRef]

41. Mitchell, R.K.; Agle, B.R.; Wood, D.J. Toward a theory of stakeholder identification and salience: Defining the principle of who and what really counts. Acad. Manag. Rev. 1997, 22, 853. [CrossRef]

42. MacKalski, R.; Bélisle, J.-F.; Belisle, R.M.-F. Erratum: Measuring the short-term spillover impact of a product recall on a brand ecosystem. J. Brand Manag. 2015, 22, 485. [CrossRef]

43. Siomkos, G.J.; Triantafillidou, A.; Vassilikopoulou, A.; Tsiamis, I. Opportunities and threats for competitors in product-harm crises. Mark. Intell. Plan. 2010, 28, 770-791. [CrossRef]

44. Bentley, J.M. What counts as an apology? Exploring stakeholder perceptions in a hypothetical organizational crisis. Manag. Commun. Q. 2017, 32, 202-232. [CrossRef]

45. Coombs, W.T.; Holladay, S.J. Helping crisis managers protect reputational assets. Manag. Commun. Q. 2002, 16, 165-186. [CrossRef]

46. Coombs, W.T. Attribution Theory as a guide for post-crisis communication research. Public Relat. Rev. 2007, 33, 135-139. [CrossRef]

47. Fairclough, N. Analyzing Discourse: Textual Analysis for Social Research; Routledge: London, UK; New York, NY, USA, 2003.

48. Kutter, A. Corpus analysis. In Routledge Handbook of Language and Politics; Wodak, R., Forchtner, B., Eds.; Routledge: London, UK, 2018; pp. 169-186.

49. McEnery, T. Corpus Linguistics. In The Oxford Handbook of Computational Linguistics; Mitkov, R., Ed.; Oxford University Press Inc.: Oxford, UK, 2012; pp. 448-463.

50. Long, Q.; Wang, W.; Deng, J.; Liu, S.; Huang, W.; Chen, F.; Liu, S. A distributed system for large-scale n-gram language models at Tencent. Proc. VLDB Endow. 2019, 12, 2206-2217. [CrossRef]

51. Yeap, D.; Hichwa, P.T.; Rajapakse, M.Y.; Peirano, D.J.; McCartney, M.; Kenyon, N.J.; Davis, C.E. Machine vision methods, natural language processing, and machine learning algorithms for automated dispersion plot analysis and chemical identification from complex mixtures. Anal. Chem. 2019, 91, 10509-10517. [CrossRef]

52. Dos Santos, F.F.; Domingues, M.A.; Sundermann, C.V.; Carvalho, V.; Moura, M.F.; Rezende, S. Latent association rule cluster based model to extract topics for classification and recommendation applications. Expert Syst. Appl. 2018, 112, 34-60. [CrossRef]

53. Eckhaus, E.; Sheaffer, Z. Managerial hubris detection: The case of enron. Risk Manag. 2018, 20, 304-325. [CrossRef]

54. Lin, X.; Spence, P.; Sellnow, T.; Lachlan, K. Crisis communication, learning and responding: Best practices in social media. Comput. Hum. Behav. 2016, 65, 601-605. [CrossRef]

55. Kassarjian, H.H. Content analysis in consumer research. J. Consum. Res. 1977, 4, 8-18. [CrossRef]

56. Sheiner, D.Z.; Earon, A. Disruptions of account planning in the digital age. Mark. Intell. Plan. 2019, 37, 126-139. [CrossRef]

57. Braun, V.; Clarke, V. Using thematic analysis in psychology. Qual. Res. Psychol. 2006, 3, 77-101. [CrossRef]

58. Giardini, F.; Vilone, D. Opinion dynamics and collective risk perception: An agent-based model of institutional and media communication about disasters. J. Artif. Soc. Soc. Simul. 2021, 24, 4. [CrossRef]

59. Bagozzi, R.P.; Edwards, J. A general approach for representing constructs in organizational research. Organ. Res. Methods 1998, 1, 45-87. [CrossRef]

60. Liu, H.; Fan, J.; Fu, Y.; Liu, F. Intrinsic motivation as a mediator of the relationship between organizational support and quantitative workload and work-related fatigue. Hum. Factors Ergon. Manuf. 2018, 28, 154-162. [CrossRef]

61. Baldofski, S.; Rudolph, A.; Tigges, W.; Herbig, B.; Jurowich, C.; Kaiser, S.; Dietrich, A.; Hilbert, A. Weight bias internalization, emotion dysregulation, and non-normative eating behaviors in prebariatric patients. Int. J. Eat. Disord. 2015, 49, 180-185. [CrossRef]

62. Kotrlik, J.; Williams, H.; Jabor, K. Reporting and interpreting effect size in quantitative agricultural education research. J. Agric. Educ. 2011, 52, 132-142. [CrossRef]

63. Bakos, L.; Dumitrașcu, D.D. Holonic crisis handling model for corporate Sustainability. Sustainability 2017, 9, 2266. [CrossRef]

64. Weiner, B. Social Motivation, Justice, and the Moral Emotions: An Attributional Approach; Psychology Press: Hove, UK, 2006.

65. Coombs, W.T.; Holladay, S.J. PR Strategy and Application: Managing Influence; Wiley-Blackwell: Oxford, UK, 2010.

66. Kovacova, M.; Kliestik, T.; Valaskova, K.; Durana, P.; Juhaszova, Z. Systematic review of variables applied in bankruptcy prediction models of visegrad group countries. Oecon. Copernic. 2019, 10, 743-772. [CrossRef]

67. Brown, J.A.; Forster, W.R. CSR and stakeholder theory: A tale of adam smith. J. Bus. Ethics 2012, 112, 301-312. [CrossRef]

68. Kliestik, T.; Misankova, M.; Valaskova, K.; Svabova, L. Bankruptcy prevention: New effort to reflect on legal and social changes. Sci. Eng. Ethics 2017, 24, 791-803. [CrossRef] [PubMed]

69. Schmiedhofer, M.; Möckel, M.; Slagman, A.; Frick, J.; Ruhla, S.; Searle, J. Patient motives behind low-acuity visits to the emergency department in germany: A qualitative study comparing urban and rural sites. BMJ Open 2016, 6, e013323. [CrossRef] [PubMed]

70. Saeed, R.M.; Rady, S.; Gharib, T.F. An ensemble approach for spam detection in Arabic opinion texts. J. King Saud Univ. Comput. Inf. Sci. 2019. [CrossRef] 
71. Sagum, R.A. Filipino native language identification using markov chain model and maximum likelihood decision rule. Turk. J. Comput. Math. Educ. (TURCOMAT) 2021, 12, 5475-5478. [CrossRef]

72. Chiu, C.; Chiu, N.-H.; Sung, R.-J.; Hsieh, P.-Y. Opinion mining of hotel customer-generated contents in Chinese weblogs. Curr. Issues Tour. 2013, 18, 477-495. [CrossRef]

73. Li, Z.; Xiong, Z.; Zhang, Y.; Liu, C.; Li, K. Fast text categorization using concise semantic analysis. Pattern Recognit. Lett. 2011, 32, 441-448. [CrossRef] 